\title{
EFEKTIVITAS PROBIOTIK SINGLE DAN MULTI STRAIN TERHADAP Escherichia coli SECARA IN VITRO
}

\author{
M. Widianingsih ${ }^{1}$, E. F. Yunita ${ }^{2}$ \\ ${ }^{1}$ Fakultas Sains, Teknologi dan Analisis \\ 2Program Studi D4 Analis Kesehatan, Fakultas IImu Kesehatan \\ Institut IImu Kesehatan Bhakti Wiyata, Kediri, Jawa Timur \\ e-mail: widianingsihmastuti910224@gmail.com, erafitria9@gmail.com
}

\begin{abstract}
ABSTRAK
Probiotik dapat dijadikan sebagai pengobatan alternatif pengganti antibiotik. Penggunaan probiotik mampu meningkatkan kesehatan host dengan cara menyeimbangkan jumlah mikroflora normal sehingga dapat meningkatkan fungsi barrier mukosa dan mencegah timbulnya infeksi. Penelitian ini bertujuan mengetahui efektivitas probiotik single strain dan multi strain terhadap $E$. coli sebagai salah satu bakteri yang sering menyebabkan diare. Metode yang digunakan adalah difusi sumuran (60 $\mu$ l) dengan lama inkubasi 3x24 jam dan pengukuran zona jernih dilakukan setiap $1 \times 24$ jam. Hasil penelitian menunjukkan probiotik multi strain lebih efektif menghambat $E$. coli. Bakteri asam laktat dalam probiotik menghasilkan asam laktat dan bakteriosin yang mengubah suasana asam sehingga menimbulkan perforasi. Kebocoran nutrisi dan masuknya senyawa antibakteri akibat lisisnya dinding sel mengakibatkan rusaknya permeabilitas membran dan hilangnya proton motive force (PMF). Kondisi tersebut akan mengganggu proses metabolisme dan kematian sel. Kesimpulan dari penelitian ini adalah penggunaan probiotik single strain dan multi strain efektif dalam menghambat $E$. coli.
\end{abstract}

Kata kunci : Efektivitas, in vitro, probiotik

\begin{abstract}
Probiotics can be used as an alternative treatment for antibiotics. The use of probiotics can increased host health by balancing the total of normal microflora so as to improve the function of mucosal barrier and prevent the occurrence of infection. The objective of this research to determine the effectivity of single strain and multi strains probiotics to $E$. coli as one of the bacteria that often causes diarrhea. The method used was the diffusion of wells (60 $\mu \mathrm{l})$ with the incubation time of $3 \times 24$ hours and the measurement of clear zone was done every $1 \times 24$ hours. The results showed that multi strain probiotics are more effective in inhibiting $\mathrm{E}$. coli. Lactic acid bacteria in probiotics produced lactic acid and bacteriocin which alters the acidic atmosphere resulting in perforation. Leakage of nutrients and the entry of antibacterial compounds due to cell wall lysis result in destruction of membrane permeability and loss of proton motive force (PMF). These conditions will interfere with metabolic processes and cell death. It would be concluded the used single strain and multi strain effective in inhibiting $E$. coli.
\end{abstract}

Keyword: Effectivity, in vitro, probiotic

\section{PENDAHULUAN}

Di Indonesia, angka kematian yang disebabkan karena bakteri masih cukup tinggi dan sangat mengkhawatirkan (Hasibuan, 2016). Muslimin (2016) menyatakan bahwa sekitar 2-10\% kasus infeksi akibat $E$. coli menyebabkan kematian, khususnya pada anak-anak. Kasus diare yang disebabkan infeksi E. coli Jurnal Sains dan Teknologi | 178 
berkisar 34,85\% (Jurnalis et al., 2009). Selain itu, sekitar $50 \%$ infeksi nosokomial, infeksi saluran kemih ( $\pm 90 \%$ ) (Geo. F. Brooks, Karen C. Carroll, Janet S. Butel, Stephen A. Morse, 2013), serta sepsis dan meningitis (Huda, 2013) juga disebabkan oleh E. coli.

E. coli merupakan salah satu jenis bakteri batang Gram negatif berukuran 0,4$0,7 \times 1,4 \mu \mathrm{m}$, motil, namun tidak memiliki spora. Bakteri tersebut sebenarnya merupakan salah satu flora normal saluran pencernaan yang berperan dalam fungsi metabolisme di dalam usus, seperti sintesis vitamin K. E. coli dikatakan sebagai bakteri oportunistik dan bersifat patogen jika berada pada jaringan di luar usus atau di luar habitatnya (Geo. F. Brooks, Karen C. Carroll, Janet S. Butel, Stephen A. Morse, 2013).

Selama ini pengobatan infeksi yang umum dilakukan dengan mengkonsumsi antibiotik. Pemilihan antibiotik yang kurang tepat dapat menimbulkan dampak negatif yaitu timbulnya resistensi bakteri dan efektivitas antibiotik yang rendah terhadap bakteri tertentu (Jurnalis et al., 2009). Sharma et al. (2009) dalam Muhajir et al .2016) menyatakan bahwa sekitar 29\% pengobatan infeksi akibat $E$. coli menunjukkan efek resisten terhadap antibiotik.

Kurangnya efek samping penggunaan probiotik menunjukkan bahwa probiotik lebih aman digunakan dibandingkan dengan antibiotik. International Life Science Institute (ILSI) mendefinisikan probiotik sebagai makanan yang apabila dikonsumsi dapat bermanfaat bagi kesehatan dengan meningkatkan sistem imun tubuh (Kusumaningsih, 2014). Selain itu, penggunaan probiotik memiliki keuntungan yaitu dapat meningkatkan kesehatan host (I. I. Arief, B. Sri Laksmi Jenie, M. Astawan, 2010) dengan cara menyeimbangkan jumlah mikroflora normal. Selain itu, probiotik memiliki aktivitas anti karsinogenik, meiningkatkan pencernaan dan absorpsi makanan, serta memodulasi innate immunity (Kusumaningsih, 2014).
Probiotik berdasarkan kandungannya, terbagi menjadi dua yaitu probiotik single dan multi strain. Probiotik single strain terdiri dari 1 strain bakteri asam laktat yang memiliki efektivitas terhadap bakteri patogen tertentu, sedangkan probiotik multi strain terdiri dari 2 atau lebih strain bakteri asam laktat yang dikombinasi dan dapat bekerja secara bersinergi dalam menghambat bakteri patogen dalam tubuh (Saxelin et al., 2010).

Jenis bakteri asam laktat yang umum digunakan dalam probiotik adalah genus Lactobacillus dan Bifidobacterium (Rahmi and Gayatri, 2015). Bifidobacterium merupakan flora normal pada usus besar, sedangkan Lactobacillus lebih dominan berada di usus kecil (Saxelin et al., 2010). Genus Lactobacillus yang memiliki kemampuan sebagai antibakteri. Bakteri tersebut mensekresikan enzim katalase yang dapat menormalkan jumlah flora normal di saluran pencernaan (Prima Nanda Fauziah, Jetty Nurhajati, 2015). Selain itu, bakteri asam laktat mampu memproduksi antimicrobial peptide yaitu senyawa protein yang memiliki berat molekul rendah yang memiliki aktivitas penghambatan ataupun membunuh bakteri, serta bertindak sebagai kofaktor immune system (Özdemir, 2010).

Prima Nanda Fauziah dan Jetty Nurhajati (2015) menyatakan bahwa Lactobacillus bulgaricus memproduksi asam laktat dan bakteriosin yang memiliki aktivitas antibakteri. Jenis Lactobacillus yang lain, seperti lactobacillus fermentum, Lactobacillus plantarum, Lactobacillus acidophilus, Lactobacillus rhamnosus, dan Lactobacillus gasseri memiliki sifat probiotik yang baik dan menunjukkan zona hambat yang luas terhadap $E$. coli dengan inkubasi 1x24 jam (Pratima Pradhan, Rama Charan Mohanty, 2011).

Lama waktu paparan probiotik memiliki korelasi positif terhadap aktivitas probiotik. Aqil et al. (2015) menyatakan paparan probiotik selama 24-72 jam ternyata mampu meningkatkan jumlah bakteri asam laktat dalam tubuh. Hal tersebut dapat menghambat pembentukan koloni bakteri 
patogen dengan adanya peningkatan jumlah bakteri asam laktat sebagai kompetitor pada reseptor adhesi.

Berdasarakan uraian tersebut di atas, tujuan penelitian ini adalah guna mengetahui efektivitas probiotik single dan multi strain dalam menghambat $E$. coli.

\section{METODE PENELITIAN}

Penelitian ini melibatkan tahap pembuatan media dan kultur bakteri, serta pengujian aktivitas probiotik single dan multi staiin yang dilakukan di Laboratorium Bakteriologi Institut IImu Kesehatan Bhakti Wiyata Kediri pada bulan Mei-Juni 2017. Desain penelitian yang digunakan yaitu eksperimental laboratorium dengan metode posttest random design. Variabel bebas (independent) yang digunakan adalah probiotik single dan multi strain, sedangkan variabel terikatnya (dependent) adalah zona hambat $E$. coli. Variabel bebas yang digunakan akan diamati efektivitasnya setiap 1x24 jam dengan 3 kali pengamatan (1×24 jam, 2x24 jam, dan 3×24 jam). Kontol yang digunakan adalah kontrol negatif yaitu aquadest steril.

Sampel yang digunakan adalah probiotik single dan multi strain. Total perlakuan yaitu 28 (Tabel 1) dengan rincian 7 perlakuan 4 ulangan yang ditentukan dengan rumus Federer (Prameswari, 2014) yaitu :

$$
(\mathrm{t}-1)(\mathrm{n}-1) \geq 15
$$

Keterangan :

$\mathrm{t} \quad=$ jumlah kelompok perlakuan

$\mathrm{n} \quad=$ jumlah ulangan

Tabel 1 Rincian Perlakuan Probiotik Single dan Multi Stain terhadap E. coli

\section{Perlakuan}

\begin{tabular}{|c|c|}
\hline $\begin{array}{l}\text { P1 } \\
\text { P2 } \\
\text { P3 } \\
\text { P4 } \\
\text { P5 } \\
\text { P6 } \\
\text { P7 }\end{array}$ & 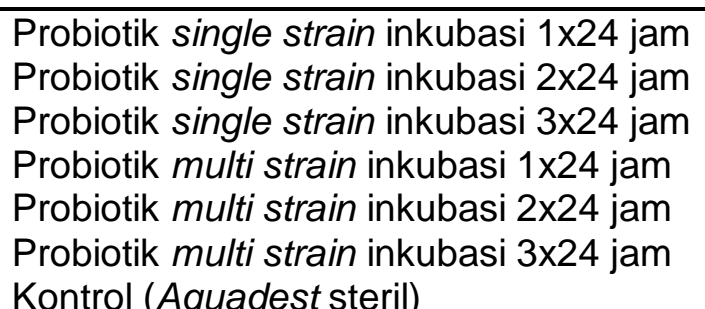 \\
\hline
\end{tabular}

Uji efektivitas probiotik dilakukan dengan metode well diffusion dengan ukuran well $60 \mathrm{\mu l}$ (Khusnul Khotimah, 2014). Efektivitas probiotik diketahui dengan terbentuknya zona jernih di sekitar sumuran yang diukur sebagai mili meter $(\mathrm{mm})$ diameter zona jernih dikurangi dengan diameter well yaitu $8 \mathrm{~mm}$ (Buadiana, S. M. A., Kojong, N. S., Wewekang, 2015).

Data yang didapatkan kemudian diuji normalitas dan homogenitas. Jika data terdistribusi normal dan homogen, maka dilanjutkan dengan uji One Way Anova guna mengetahui ada tidaknya perbedaan tiap perlakuan probiotik single dan multi strain terhadap E. colidengan taraf kesalahan 5\%. Uji Duncan's Multiple Range Test (DMRT) dilakukan jika terdapat perbedaan antar perlakuan.

\section{Alat dan Bahan}

\section{Alat}

Alat yang digunakan meliputi tabung reaksi, rak tabung, erlenmeyer, neraca analitik, spatel, tabung reaksi, plate, ose bulat, pecadang baja, aluminium foil, cotton swab, pinset, inkase, jangka sorong, micropipette, yellow tip, blue tip, pengaduk, bunsen, korek api, kertas label, alat tulis, tisu, pinset, inkubator, dan kamera sebagai alat dokumentasi.

\section{Bahan}

Bahan yang digunakan meliputi kultur E. coli, probiotik single dan multi strain, 
Nutrient Agar (NA), Nutrient Broth (NB), Mac Conkey Agar (MCA), Eosin Methylene Blue (EMB), alkohol $70 \%$, spirtus, $\mathrm{H}_{2} \mathrm{SO}_{4} 1 \%$, $\mathrm{BaCl}_{2} 1 \%, \quad \mathrm{NaCl} 0,9 \%$, swab steril, alumunium foil, dan aquadest steril.

\section{Prosedur Penelitian}

a. Pembuatan larutan McFarland (McFarland, 1907)

Larutan $\mathrm{H}_{2} \mathrm{SO}_{4} 1 \%$ sebanyak $9,5 \mathrm{ml}$ dicampurkan dengan larutan $\mathrm{BaCl}_{2} 1 \%$ sebanyak $0,5 \mathrm{ml}$ dalam tabung reaksi. Larutan kemudian dihomogenkan sampai terbentuk larutan yang keruh. Kekeruhan ini dipakai sebagai standar kekeruhan suspensi bakteri uji.

b. Peremajaan bakteri (Castro-rosas et al., 2012)

Proses peremajaan bakteri dimulai dengan pembuatan media pemupuk, media diferensial, dan media selektif untuk E. coli. Pembuatan media dilakukan dengan cara steril yaitu sterilisasi alat dilakukan dengan menggunakan oven (suhu $170^{\circ} \mathrm{C}$ ) dan sterilisasi media menggunakan autoclave $\left(121^{\circ} \mathrm{C} ; 1,5 \mathrm{~atm}\right)$. Koloni E. coli ditanam pada media pemupuk Nutrient Broth kemudian inkubasi 1x24 jam. Tujuannya adalah untuk memperbanyak jumlah bakteri tersebut. Hari kedua dilakukan inokulasi pada media Mac Conkey Agar (MCA) kemudian inkubasi 1x24 jam. Hari ketiga, koloni yang tumbuh pada media MCA selanjutnya diinokulasi pada media EMB. Koloni berwarna hijau methalic sheen yang tumbuh setelah masa inkubasi 1x24 jam pada media tersebut merupakan koloni $E$. coli.

c. Pembuatan suspensi E. coli (Nua, A. R., Fatimawali, Widdhi, 2016)

E. coli hasil peremajaan diambil dengan jarum ose steril lalu disuspensikan ke dalam tabung yang berisi $5 \mathrm{ml}$ larutan $\mathrm{NaCl}$ 0,9\% hingga diperoleh kekeruhan yang sama dengan standar kekeruhan larutan McFarland. Apabila kekeruhan suspensi E. coli sama dengan kekeruhan standart maka diartikan bahwa jumlah bakteri $1,5 \times 10^{9} / \mathrm{ml}$ d. Pembuatan larutan probiotik (Andhika Agus Setyawan, Sukanto, 2014)

Probiotik dilarutkan dengan rumus $\mathrm{b} / \mathrm{v}$ dengan $\mathrm{b}$ adalah massa (gram) dan $\mathrm{v}$ sebagai volume $(\mathrm{ml})$ dengan konsentrasi $100 \%$ untuk masing-masing probiotik. Pembuatan konsentrasi dilakukan dengan cara menimbang sebanyak $1 \mathrm{~g}$ probiotik single dan multi strain kemudian masing-masing probiotik dilarutkan dalam $1 \mathrm{ml}$ aquadest steril.

e. Pembuatan media pengujian probiotik (Buadiana, S. M. A., Kojong, N. S., Wewekang, 2015)

Nutrient Agar (NA) merupakan media yang digunakan pada pengujian probiotik. Sebanyak 5 pecandang baja diletakkan pada plate diatur sedemikian rupa jaraknya agar daerah pengamatan tidak saling bertumpuh. Setelah itu, media NA dituang secara hati-hati ke dalam plate kurang lebih sebanyak $10 \mathrm{ml}$. Jika media sudah memadang, maka pecandang baja dapat dilepaskan dari media NA dan media siap digunakan untuk pemeriksaan aktivitas probiotik.

f. Pemeriksaan aktivitas probiotik (Buadiana, S. M. A., Kojong, N. S., Wewekang, 2015)

Ketentuan pemeriksaan adalah dalam 1 plate diisi dengan 1 jenis probiotik saja (misalnya hanya probiotik single strain saja). Suspensi E. coli digoreskan pada media NA secara merata dengan menggunakan swab steril. Sebanyak $60 \mu \mathrm{l}$ larutan probiotik single dan multi strain dimasukkan pada masing-masing well pada tiap plate (4 well untuk probiotik), kemudian 1 well dimasukkan $60 \mu \mathrm{l}$ aquadest steril sebagai kontrol negatif (Khikmah, 2015). Inkubasi selama 3x24 jam dengan kombinasi waktu pengamatan zona hambat yaitu 1x24 jam, 2x24 jam, dan 3x24 jam. 


\section{HASIL DAN PEMBAHASAN}

Probiotik single strain merupakan probiotik yang terdiri dari satu bakteri asam laktat, sedangkan probiotik multi strain mengandung lebih dari satu bakteri asam laktat yang bekerja secara bersinergi dalam menghambat bakteri patogen (Saxelin et al., 2010). Pengujian efektivitas kedua probiotik tersebut dilakukan dengan metode well diffusion terhadap E. coli.

Pengamatan dilakukan dengan 4 kali pengulangan untuk masing-masing probiotik. Inkubasi pada suhu inkubator $37^{\circ} \mathrm{C}$


jam. Kemampuan penghambatan probiotik terhadap $E$. coli ditunjukkan dengan adanya zona jernih di sekitar well.

Uji normalitas dan uji homogenitas harus dilakukan sebelum data dianalisa dengan One Way Anova. Uji normalitas dilakukan menggunakan Shapiro-wilk karena jumlah data yang diperoleh kurang dari 50. Berdasarkan Tabel 2 menunjukkan bahwa data yang didapat pada penelitian ini normal (sig.>0,05) dan terdistribusi secara homogen (sig.>0,05) (Tabel 3), sehingga dapat dilanjutkan dengan uji One Way Anova. Uji tersebut bertujuan untuk mengetahui ada tidaknya perbedaan antar perlakuan.

Berdasarkan hasil One Way Anova menunjukkan bahwa probiotik single dan multi strain mempunyai aktivitas antibakteri yang berbeda terhadap E. coli. Hasil uji tersebut menunjukkan adanya perbedaan antar perlakuan probiotik single dan multi strain yang ditunjukkan dengan nilai $F$ hitung lebih besar dari $F$ tabel pada tingkat signifikasi kurang dari 0,05 (Tabel 4).

Tabel 2. Uji Normalitas

\begin{tabular}{clccc}
\hline & \multicolumn{1}{c}{$\begin{array}{c}\text { Probiotik dan Waktu } \\
\text { Inkubasi }\end{array}$} & \multicolumn{3}{c}{ Shapiro-Wilk $^{\mathbf{a}}$} \\
\cline { 2 - 5 } & \multicolumn{1}{c}{ Statistic } & Df & Sig. \\
\cline { 2 - 5 } Diameter (Single strain 1x24 jam) &, 763 & 4 &, 051 \\
zona hambat & P2 (Single strain 2x24 jam) &, 927 & 4 &, 577 \\
& P3 (Single strain 3x24 jam) &, 927 & 4 &, 577 \\
& P4 (Multi strain 1x24 jam) &, 927 & 4 &, 855 \\
& P5 (Multi strain 2x24 jam) &, 963 & 4 &, 798 \\
& P6 (Multi strain 3x24 jam) &, 801 & 4 &, 103 \\
\hline
\end{tabular}

Keterangan :

Kontrol (P7) memiliki diameter zona hambat yang konstan yaitu $8 \mathrm{~mm}$

Tabel 3. Uji Homogenitas

\begin{tabular}{ccccc}
\hline Diameter zona & Levene Statistic & df1 & df2 & Sig. \\
\cline { 2 - 5 } hambat & 1,865 & 6 & 21 &, 135 \\
\hline
\end{tabular}

Tabel 4. Uji One Way Anova

\begin{tabular}{clccccc}
\hline & \multicolumn{1}{c}{ Sum of Squares } & Df & Mean Square & F & Sig. \\
\cline { 2 - 7 } Diameter & Between & 325,357 & 6 & 54,226 & 11,002 &, 000 \\
zona & Group & & & & & \\
hambat & Within & 103,500 & 21 & 4,929 & & \\
& Group & 428,857 & 72 & & & \\
\hline
\end{tabular}

\section{Keterangan :}

Taraf signifikansi $<0,05$ 
Huruf yang tertera pada diameter zona hambat Tabel $\mathbf{5}$ menunjukkan letak perbedaan antar tiap perlakuan yang diberikan pada E. coli. Tidak hanya jenis probiotik yang berpengaruh terhadap penghambatan $E$. coli namun juga lama waktu inkubasi (Gambar 1). Di penelitian ini, digunakan 3 variasi waktu inkubasi yaitu 1×24 jam, 2x24 jam, dan 3×24 jam. Hal tersebut dikarena golongan bakteri asam laktat mampu menghambat pertumbuhan bakteri patogen dalam kurun waktu tertentu. Selain itu, jenis bakteri asam laktat membutuhkan lama waktu yang berbedabeda dalam meningkatkan jumlah senyawa antibakteri berupa asam-asam organik (Yuliana, Afrianto and Pratama, 2015).

Senyawa bakteriosin mampu merusak permeabilitas membran dan juga menghilangkan proton motive force (PMF) sehingga dapat menghambat produksi energi dan juga biosintesis protein. Proton motive force berfungsi menjaga keseimbangan $\mathrm{pH}$ asam intraseluler. Mekanisme aktivitas bakterisidal bakteriosin terjadi melalui kontak langsung bakteriosit dengan membran sel. Proses ini mampu mengganggu destabilitas membran sehingga mengakibatkan perforasi melalui gangguan PMF (Sunaryanto, 2015).

Tabel 5. Rata-rata zona hambat probiotik single dan multi strain terhadap E. coli secara in vitro

\begin{tabular}{clc}
\hline Perlakuan & \multicolumn{1}{c}{ Probiotik } & Diameter zona hambat $(\mathrm{mm})$ \\
\hline P1 & Single strain 1×24 jam & $3,50^{\mathrm{b}}$ \\
P2 & Single strain 2x24 jam & $8,00^{\text {cd }}$ \\
P3 & Single strain 3x24 jam & $8,00^{\text {cd }}$ \\
P4 & Multi strain 1x24jam & $5,50^{\text {bc }}$ \\
P5 & Multi strain 2x24jam & $9,75^{\mathrm{d}}$ \\
P6 & Multi strain 3x24jam & $10,25^{\mathrm{d}}$ \\
P7 & Kontrol & $0,00^{\mathrm{a}}$ \\
\hline
\end{tabular}

Keterangan:

Huruf yang berbeda menunjukkan letak perbedaan antar perlakuan

Gangguan PMF salah satunya adalah reduksi PMF. Apabila PMF berkurang, proton yang berasal dari substansi ekstraseluler dapat masuk secara berlebihan ke dalam sel. Hal tersebut dapat mengganggu fungsi metabolik, sehingga menyebabkan ketidakmampuan sel dalam mengangkut nutrisi dan mempertahankan konsentrasi molekul kofaktor yang berakibat pada terjadinya kematian sel bakteri patogen (Khusnul Khotimah, 2014).

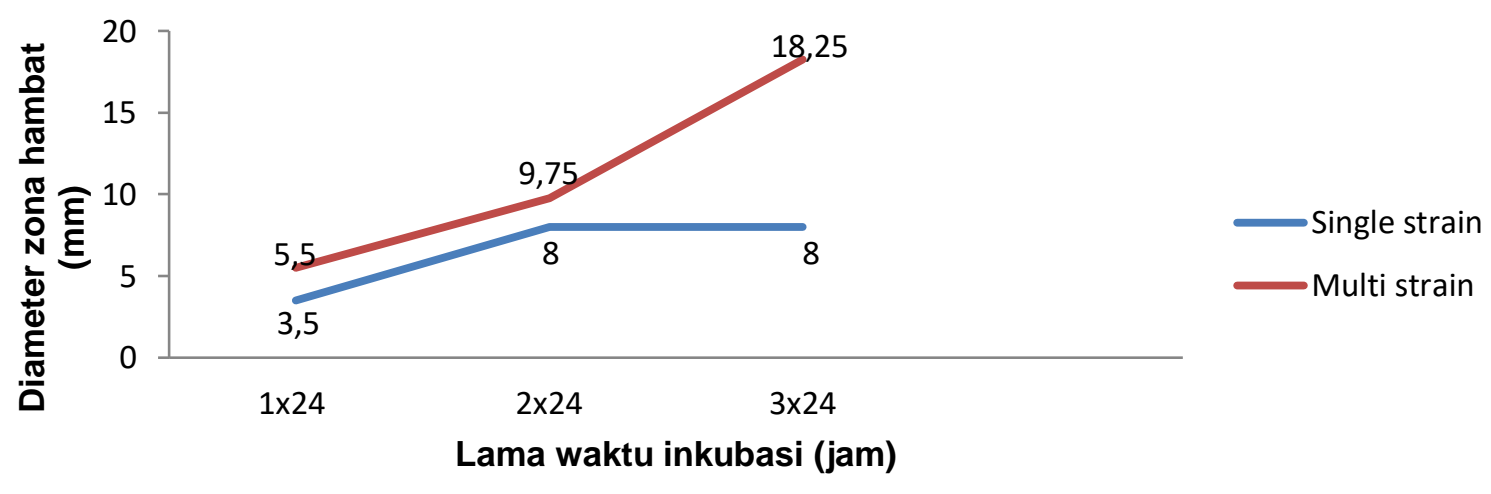

Gambar 1. Efektifitas rata-rata probiotik single strain dan multi strain terhadap E. coli 
Zona hambat yang terbentuk berbanding lurus dengan lamanya waktu inkubasi (Gambar 1). Pembentukan zona hambat pada perlakuan probiotik multi strain lebih besar jika dibandingkan dengan probiotik single strain dalam menghambat $E$. coli. Hal ini didukung oleh Pratima Pradhan dan Rama Charan Mohanty (2011) yang menyatakan bahwa probiotik multi strain memiliki efektivitas lebih tinggi dalam menghambat pertumbuhan bakteri patogen. Lactobacillus acidophillus W55, Lactobacillus casei W56, Lactobacillus salivarius W57, Bifidobacterium lactis W55, Bifidobacterium lactis W55, Bifidobacterium lactis W56, dan Lactococcus lactis W58 merupakan komposisi penyusun probiotik multi strain yang digunakan pada penelitian ini.

Semakin banyak jumlah bakteri asam laktat (BAL) yang ada di dalam probiotik akan berkorelasi positif terhadap jumlah senyawa antibakteri dan zona hambat yang terbentuk. Asam laktat dan asam asetat yang dibentuk oleh bakteri asam laktat penting dalam pembentukan senyawa antibakteri. Senyawa antibakteri yang dihasilkan seluruh bakteri dalam probiotik multi strain saling berasosiasi sehingga dalam menghambat bakteri patogen (Saxelin et al., 2010)sehingga dihasilkan spektrum penghambatan yang luas (Mirdalisa and Zakaria, 2016).

Kerusakan dinding sel akibat adanya asam laktat mampu merusak permeabilitas E. coli. Peningkatan suasana asam mampu menyebabkan lisisnya dinding sel bakteri, sehingga pertumbuhan akan terhambat bahkan $E$. coli tidak dapat tumbuh dalam kondisi tersebut (Anik Maunatin, 2012; Dwi Isyana Achmad, Risa Nofiani, 2012). Kerusakan dinding sel mengakibatkan senyawa antibakteri lainnya seperti diasetil, hidrogen peroksida, dan bakteriosin akan masuk ke sitoplasma kemudian merusak aktivitas intraselular yang berakhir pada kematian bakteri patogen (Dwi Isyana Achmad, Risa Nofiani, 2012; Khikmah, 2015; Prima Nanda Fauziah, Jetty Nurhajati, 2015).
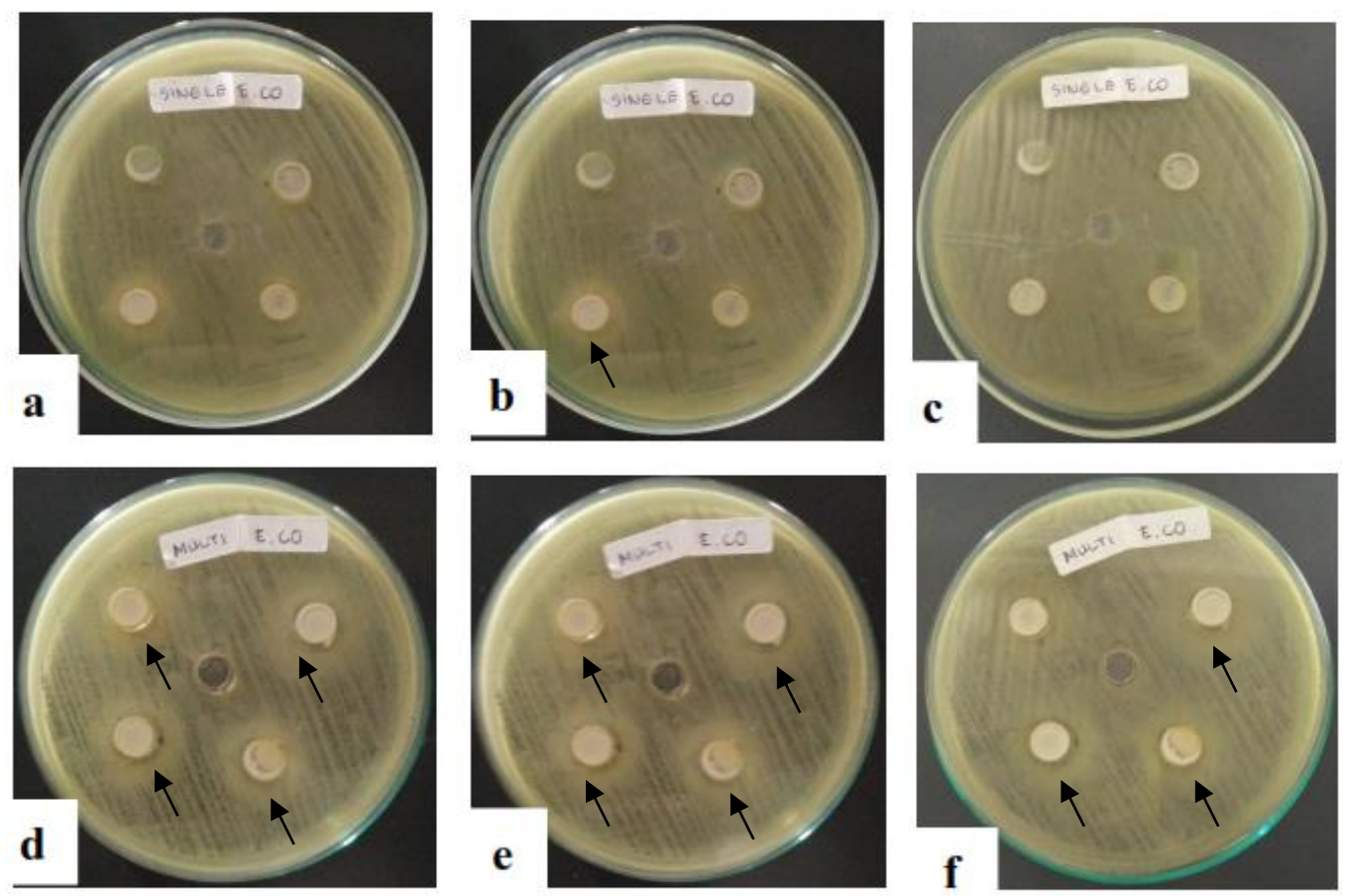

Gambar 2. Zona hambat probiotik single dan multi strain terhadap E. coli. Keterangan : (a-c) Probiotik single strain (a) inkubasi 1x24 jam; (b) inkubasi 2x24 jam; (c) inkubasi 3x24 jam. (d-f) Probiotik multi strain (d) inkubasi 1x24 jam; (e) inkubasi 2x24 jam; (f) inkubasi 3x24 jam. Tanda panah menunjukkan zona hambat. 
Selain itu, E. coli tidak memiliki asam teikoat dan komposisi peptidoglikan yang lebih sedikit jika dibandingkan dengan bakteri Gram positif, sehingga dinding sel $E$. coli lebih rentan terhadap kerusakan mekanik (Cotter and Hill, 2003 dalam Khikmah, 2015). Selain itu, rusaknya permeabilitas sel dapat menyebabkan kebocoran nutrisi dan terganggunya metabolisme sel yang berakibat pada kematian bakteri (Dwi Isyana Achmad, Risa Nofiani, 2012).

Pada penelitian ini, zona hambat yang terbentuk tidak jernih (agak berkabut) (Gambar 2). Hal ini diduga terjadi kontaminasi mikroba lain berupa jamur saat penelitian karena ketidakmampuan bakteri asam laktat dalam menghambat pertumbuhan jamur. Menggelea, F. P., Posangi, J., Wowor, M. W. (2015) menyatakan bahwa zona hambat berupa zona jernih dapat terbetuk pada waktu inkubasi kurang dari 24 jam, sehingga zona tersebut dapat ditumbuhi oleh mikroorganisme yang lainnya.

\section{SIMPULAN DAN SARAN}

\section{SIMPULAN}

Simpulan penelitian ini adalah probiotik multi strain lebih efektif dibandingkan probiotik single strain terhadap E. coli. Hal tersebut ditunjukkan dengan pembentukan zona hambat pada kombinasi lama inkubai 1x24 jam, 2x24 jam, dan 3x24 jam.

\section{SARAN}

Dilakukan penelitian uji efektivitas probiotik menggunakan probiotik single dan multi strain dengan komposisi bakteri asam laktat yang berbeda. Selain itu, uji yang dilakukan sebaiknya dibandingkan dengan antibiotik, sehingga dapat diketahui tingkat keefektivan antara probiotik dengan antibiotik.

\section{DAFTAR PUSTAKA}

ANDHIKA AGUS SETYAWAN, SUKANTO, E. W. (2014) 'POPULASI BAKTERI ASAM LAKTAT PADA BUDIDAYA IKAN NILA', Scripta Biologica, 1(1), pp. 91-95.

Anik Maunatin, K. (2012) 'UJI POTENSI PROBIOTIK Lactobacillus plantarium SECARA IN-VITRO', Alchemy, 2(1), pp. 26-34.

Aqil, H., Risdianto, D., Studi, P., Kimia, T. and Hasyim, U. W. (2015) 'ISOLASI DAN PENGAYAAN BAKTERI LACTOBACILLUS DARI RUMEN SAPI', Momentum, 11(2), pp. 93-98.

Buadiana, S. M. A., Kojong, N. S., Wewekang, D. S. (2015) 'Uji Aktivitas Antibakteri Ekstrak Pacar Air (Impatiens balsamina L.) Terhadap Pertumbuhan Bakteri Staphylococcus aureus, Pseudomonas aeruginosa, dan Escherichia coli secara In Vitro.', Jurnal IImiah Farmasi, 4(4), pp. 214223.

Castro-rosas, J., Cerna-cortés, J. F., Méndez-reyes, E., Lopez-hernandez, D., Gómez-aldapa, C. A. and Estradagarcia, T. (2012) 'International Journal of Food Microbiology Presence of faecal coliforms, Escherichia coli and diarrheagenic $E$. coli pathotypes in ready-to-eat salads, from an area where crops are irrigated with untreated sewage water', International Journal of Food Microbiology. Elsevier B.V., 156(2), pp. 176-180. doi: 10.1016/j.ijfoodmicro.2012.03.025.

Dwi Isyana Achmad, Risa Nofiani, P. A. (2012) 'KARAKTERISASI BAKTERI ASAM LAKTAT Lactobacillus sp. RED 1 DARI CINCALOK FORMULASI 1', Jurnal Kimia Khatulistiwa, 1(2), pp. 12-18.

Geo. F. Brooks, Karen C. Carroll, Janet S. Butel, Stephen A. Morse, T. A. M. 
(2013) Medical Microbiology. TwentySix. Mc Grow Hill USA.

Hasibuan, S. A. (2016) 'COMPARISON THE INHIBITION OF LEAVE EXTRACT Jatropha curcas Linn AGAINST Staphylococcus aureus AND Escherichia coli BACTERIA VIA IN VITRO', pp. 19-20.

Huda, M. (2013) 'Pengaruh Madu Terhadap Pertumbuhan Bakteri Gram Positif ( Staphylococcus Aureus ) Dan Bakteri Gram Negatif ( Escherichia Coli ) Effect On The Growth Of Honey grampositive bacteria ( Staphylococcus aureus ) and Gram-negative bacteria ( Escherichia coli )', Jurnal Analis Kesehatan, 2(1), pp. 250-259.

I. I. Arief, B. Sri Laksmi Jenie, M. Astawan, dan A. B. W. (2010) 'Efektivitas Probiotik Lactobacillus plantarum 2C12 dan Lactobacillus acidophilus 2B4 Sebagai Pencegah Diare pada Tikus Percobaan', Media Peternakan, (2000), pp. 137-143. doi: 10.5398/medpet.2010.33.3.137.

Jurnalis, Y. D., Sayoeti, Y., IImu, B. and Anak, K. (2009) 'POLA RESISTENSI KUMAN PENYEBAB DIARE TERHADAP ANTIBIOTIKA', Majalah Kedokteran Andalas, 33(1), pp. 42-47.

Khikmah, N. (2015) 'Uji ANtibakteri Susu Fermentasi Komersial Pada Bakteri Patogen', Jurnal Penelitian Saintek, 10(1), pp. 45-52.

Khusnul Khotimah, J. K. (2014) 'dactilyfera L . ) MENGGUNAKAN Lactobacillus plantarum DAN Lactobacillus casei Antibacterial Activity of Probiotic Date Fruit ( Phoenix dactilyfera L .) Beverages Using Lactobacillus plantarum and Lactobacillus casei', Jurnal Pangan dan Agroindustri, 2(3), pp. 110-120.

Kusumaningsih, T. (2014) 'Peran bakteri probiotik terhadap Innate Immune Cell ( The role of probiotic bacteria on
Innate Immune Cells )', Oral Biology Journal, 6(2), pp. 45-50.

Menggelea, F. P., Posangi, J., Wowor, M. W., B. R. (2015) 'Uji Efek Antibakteri Jamur Endosimbion Spons Laut Callyspongia sp. Terhadap Bakteri Pseudomonas aeruginosa dan Eschericia coli', Jurnal e-Biomedik, 3(1), pp. 376-380.

Mirdalisa, C. A. and Zakaria, Y. (2016) 'Efek Suhu dan Masa Simpan Terhadap Aktivitas Antimikroba Susu Fermentasi dengan Lactobacillus casei', Agripet, 16(1), pp. 49-55.

Muhajir, A. S., Purwono, P. B., Handayani, S., IImu, D., Masyarakat, K., Kedokteran, F., Airlangga, U., Muhajir, A. S., Purwono, P. B. and Handayani, S. (2016) 'Gambaran Terapi dan Luaran Infeksi Saluran Kemih oleh Bakteri Penghasil', Sari Pediatri, 18(2), pp. 111-116.

Muslimin, L. (2016) 'Zoonotik Bakteri Patogen Escherichia coli O157:H7 Penyebab Food Borne Disease', Seminal Nasional Ke-4, 21(2), pp. 3138.

Nua, A. R., Fatimawali, Widdhi, B. (2016) ‘Uji Kepekaan Bakteri Yang Diisolasi Dan Diidentifikasi Dari Urin Penderitalnfeksi Saluran Kemih (ISK) Di RSUP Prof. Dr. D. Kandaou Manado Terhadap Antibiotik Cefixime, Ciprofloxacin Dan Contrimoksazole', Jurnal Ilmiah Farmasi, 6(4), pp. 174181.

Özdemir, Ö. (2010) 'Various effects of different probiotic strains in allergic disorders: an update from laboratory and clinical data', The Journal of Translational Immunology, 160, pp. 295-304. doi: 10.1111/j.13652249.2010.04109.x.

Prameswari, N. . (2014) '( Carica papaya L ) SEBAGAI ANTI BAKTERI TERHADAP BAKTERI Escherichia 
coli'. Jakarta: Fakultas Kedokteran dan IImu Kesehatan, Universitas Islam Negeri Syarif Hidayatullah.

Pratima Pradhan, Rama Charan Mohanty, and A. M. (2011) 'SELECTION OF PROBIOTIC LACTOBACILLUS SPECIES TO ERADICATE RESISTANT UROGENITAL PATHOGENS IN PREGNANT WOMEN', International Journal of Probiotik and Prebiotics, 6(1), pp. 1320.

Prima Nanda Fauziah, Jetty Nurhajati, C. (2015) 'Daya Antibakteri Filtrat Asam Laktat dan Bakteriosin Lactobacillus bulgaricus KS1 dalam Menghambat Pertumbuhan Klebsiella pneumoniae Antibacterial Effect of Lactic Acid Filtrate and Bacteriocins of Lactobacillus bulgaricus KS1 on Inhibiting the Growth of', Majalah Kedokteran Bandung, 47(1), pp. 3541.

Rahmi, D. and Gayatri, P. (2015) 'Laporan kasus berbasis bukti Manfaat Pemberian Probiotik pada Diare Akut', Sari Pediatri, 17(71), pp. 76-80.

Saxelin, M., Tynkkynen, S., Salusjärvi, T., Kajander, K., Mattila-sandholm, T., Korpela, R. and Myllyluoma, E. (2010) 'Developing a multispecies probiotic combination 1,2', International Journal of Probiotics and Prebiotics, 5(4), pp. 169-182.

Sunaryanto, R. (2015) 'ISOLASI DAN KARAKTERISASI BAKTERIOSIN YANG DIHASILKAN OLEH Lactobacillus lactis DARI SEDIMEN LAUT Isolation and Characterization of Bacteriosin from Lactobacillus lactis Isolated from Marine Sediment', JPB Kelautan dan Perikanan, 10(1), pp. $11-18$.

Yuliana, G., Afrianto, E. and Pratama, I. (2015) 'Aplikasi Kombinasi Bakteri Asam Laktat, Natrium Klorida Dan
Natrium Asetat Terhadap Masa Simpan Ikan Patin ( Pangasius hypophtalmus ) Pada Suhu Rendah', Jurnal Perikanan Kelautan, VI(2), pp. 85-90. 